\title{
The cheap crusade
}

Fight the system.

\section{Rahul Kanakia}

Everybody knows not to click on the spam link. Nowadays, the best thing that can happen is a virus. But when it's late at night, you just say to hell with it, like that time in middle school when you tremulously clutched the sides of the sink and whispered "Bloody Mary" three times into the mirror just to see if she'd really show up to flay you alive.

And when the site pops up, you know you should close it right away. Because the NSA has profiles for guys like you: middle-aged stockbrokers with a gun in the drawer. They apply Bayesian analysis to reams of stats: number of pages viewed, order viewed, time viewed, interval between clicks and so on. And eventually they decide there's a non-negligible chance that you've been turned. That's when your name appears on a list. You probably won't be arrested. But you'll never get off that list.

Yet you keep reading, because the terrorists have studied you too. They bought your stats from the same corporations that sell it to the government. How do you think they even got your e-mail address? And they feed it to analysts trained, using petrodollar scholarships, at the same Harvard labs that the CIA recruits from. They know how to get your heart pumping

Oh, the terrorists don't know you will be the one who takes the bait. Out of 50 million of these e-mails sent every day, they'll be lucky to get one nibble. But they know that there's someone like you out there. And they keep e-mailing you, so you'll always have that link in your inbox at just the moment when you're at your weakest.

As you read, you feel an ecstatic rush, like when you beat your fist against the wall until the knuckles bleed or when you stop at the threshold of your door just before work, look back at the fridge, and decide to make yourself what you know will be only the first Bloody Mary of the day.

Except that this feeling is ten times better. This time there won't be a cold morning after, when you have to drag yourself through the pieces of your life, praying that today God will finally grant you the strength to resist temptation.

Only moments after you realize what you've done, a computer in Washington does too. And then the clock starts ticking. It will take only a few hours for an agent to contact your Internet service provider and find your name and address. Then he'll deputize a few of your neighbours and

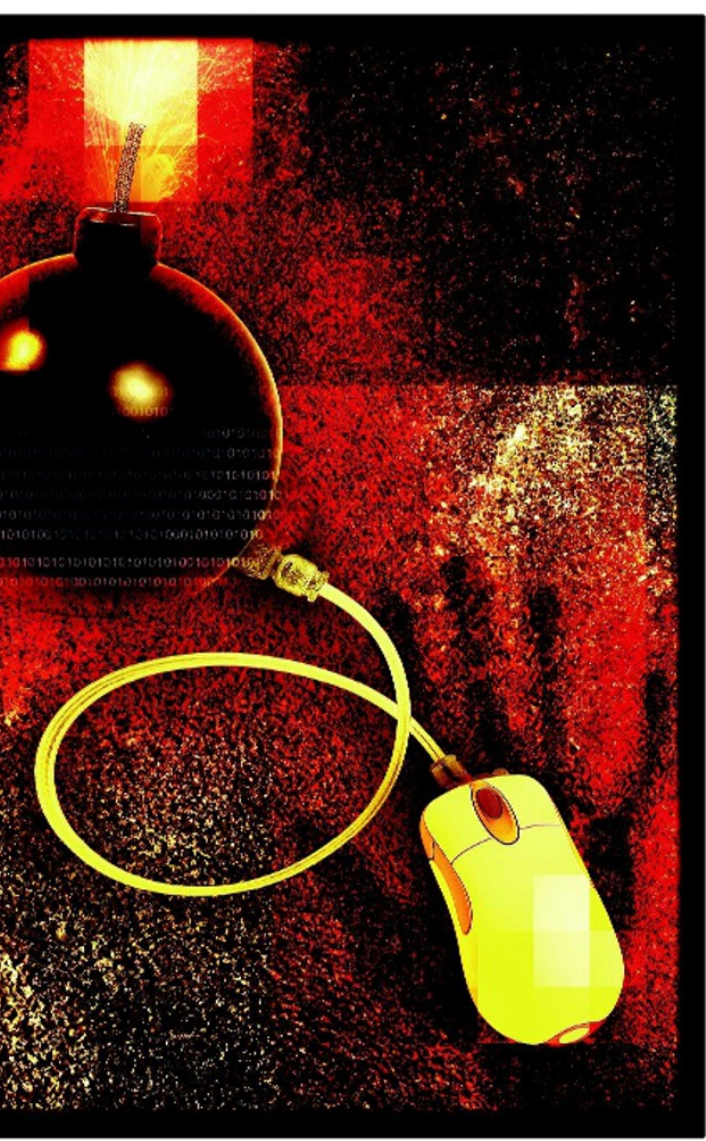

co-workers, under the militia clause of the Constitution, and tell them to look out for you. You won't know who they are. Hell, you've been deputized yourself.

Then you'll be truly stuck. They'll kill that little flower you've nurtured in your heart ever since you first realized what a sorry, pathetic bastard you are. Sometimes it was the only thing that kept you going as you sat at your desk, starting to regret that buzz and calculating when you could pop out to renew it.

Anytime you wanted to, you could make them pay. Oh, you wouldn't. You'd never do anything like that. But you could. And in some way, holding back gave you a kind of pride. No one knew the kind of strength it took. You were protecting them, through sheer force of will, every minute of every day. Still, it gave you a thrill to know what you could do.

But as you read, you realize that this is your last chance. Sure you can close this window, and report to work tomorrow, but they'll know. Wherever you go, they'll know. And if you ever stray; if you have irregularities in your tax statements or get into a bar fight, someone will whisper in the judge's ear, and there'll be no leniency for the likes of you.

This is good for some people. You've seen them on TV. They stared down the abyss, and they walked away. They got help. They recovered. Maybe that was why you really clicked on the link. You've always hoped that the right prayer would flip that switch inside of you, and you'd be better.

But maybe the switch flipped the other way. They make it so easy to get it done, right there. There's a field for your credit card and bank account info. Within hours they'll have laundered your money so tight that the CIA can't touch it. They have a text field where you can write a message. In 12 hours, they'll send it to everyone you know.

Then come the planning pages. They know you've been revising your plan for years. But there are still some helpful suggestions, if you want them. How to derail a train with an SUV (bonus points for lying in wait and gunning down the medics); how to make a poison pill from simple household items, as they know the last thing you want is to survive your apotheosis.

Hopefully, as you drive to the tracks with a copy of the train schedule taped to the dash and a bottle of whiskey on the passenger seat, you'll pull over and take your suicide concoction. It will be a victory of a sort.

Although, that message will still go out, and then they'll know that you even managed to fail at this.

Rahul Kanakia is a recent college graduate living in San Francisco. 